\title{
Diseminasi Hasil Riset Anti Mikroba Alami Berbasis Pemanfaatan Limbah Kulit Buah Menjadi Hand Sanitizer Di Sentra Industri Keripik Pisang
}

\author{
Dewi Sartika*1, Susilawati2, Neti Yuliana3 \\ 1,2,3Program Studi Teknologi Industri Pertanian, Fakultas Pertanian, Universitas Lampung \\ *e-mail: $\underline{\text { dewikincai@yahoo.com }}{ }^{1}, \underline{\text { susilawati thp@unila.ac.id }}{ }^{2}$
}

\begin{abstract}
The Center for Home Industry chips on Bandar Lampung. The problem of this is the waste that has not been managed properly, the chip waste IRT waste in the form of fruit peels, leaves, fruit stalks, humps has the potential to be made of high-selling value products, diversification can be in the form of hand sanitizer products. The purpose of this activity is to solve the Partner's problem by disseminating research results in the form of transfer of waste treatment technology into a hand sanitizer. The method used is lectures and discussions on the dissemination of research results, assistance in processing wastewater into hand sanitizer products. The need for partners to process waste products into products that have value in the form of making herbal solid soap, followed by liquid soap, hand sanitizer, natural anti-microbial, feed making, composting and liquid fertilizer. The percentage increase in knowledge and understanding of the material after the service activities is the utilization of waste (40\%), making feed (50\%), making hand sanitizer (70\%).
\end{abstract}

Keywords: Fruit Peel Waste, Hand Sanitizer, Natural Anti-Microbial

\begin{abstract}
Abstak
Terdapat Sentra Industri Rumah Tangga keripik pisang di Bandar lampung. Permasalahan dari IRT keripik ini adalah Limbah buangan yang belum dikelola dengan baik, limbah buangan IRT keripikyang berupa kulit buah, daun, tangkai buah, bonggol sangat berpotensi untuk dibuat produk yang bernilai jual tinggi, diversifikasinya dapat berupa produk hand sanitizer. Tujuan kegiatan ini adalah memecahkan permasalahan Mitra dengan cara diseminasi hasil riset berupa transfer teknologi pengolahan limbah menjadi hand sanitizer. Metode yang dilakukan adalah ceramah dan diskusi diseminasi hasil riset, pendampingan pengolahan limbah buangan menjadi produk hand sanitizer. Kebutuhan mitra untuk mengolah produk limbah menjadi produk yang mempunyai nilai berupa pembuatan sabun padat herbal, diikuti sabun cair, hand sanitizer, anti mikroba alami, pembuatan pakan, pembuatan kompos dan pupuk cair. Prosentase peningkatan pengetahuan dan pemahaman materi setelah kegiatan pengabdian adalah pemanfaatan limbah buangan (40\%), pembuatan pakan (50\%), pembuatan hand sanitizer (70\%).
\end{abstract}

Kata kunci: Limbah Kulit Buah, Anti Mikroba Alami, Hand Sanitizer

\section{PENDAHULUAN}

Kawasan Sentra Industri Keripik adalah sentra oleh-oleh makanan khas Lampung. Pada industri keripik pisang ini ternyata menghasilkan limbah buangan yaitu kulit, bonggol, yang biasanya dibuang pada aliran sungai di belakang kawasan ini, padahal pisang dan kulit pisang masih memiliki potensi untuk dikembangkan dalam bentuk lain. Menurut Syarifudin dan Hamzah (2019), bahwa limbah batang pisang dapat dikelola menjadi produk yang memiliki nilai ekonomi dan ramah ligkungan. Bahan-bahan buangan pertanian berpotensi untuk dimanfaatkan kembali yaitu: sumber asam-asam organik (Undadraja dan Sartika, 2018); sumber antimikroba alami (Sartika et al (2016), Sartika et al (2017), dan Sartika et al (2018)). Kandungan tinggi antioksidan yang tinggi pada pisang berpotensi sebagai pengawet pangan (Sartika et al, 2017). Pengawet pangan dapat menurunkan cemaran mikrobia pangan (Sartika, 2018). Menurut Sartika et al (2017) kulit pisang berpotensi sebagai anti mikroba alami; begitu juga singkong konsumsi (Iswandari, Sartika, dan Astuti, 2017); singkong karet racun (Hartari, Sartika and Suharyono, 2018), kulit buah naga (Sartika et al, 2018), dan tomat cherry (Sartika et al, 2018). Selain tumbuhan ternyata bacteriophage pun berpotensi sebagai anti mikroba alami (Sartika et al, 2012) dan Sartika (2018)), bahkan aman ketika diuji coba in-vivo pada tikus sprague dawley (Sartika et 
al, 2012). Anti mikroba alami bisa dimanfaatkan untuk bahan baku pembuatan hand sanitizer. Hand sanitizer berbahan anti mikroba alami sangatlah aman (safety) dibandingkan dengan yang ada di pasaran saat ini karena menggunakan bahan baku sintetis (Arhany, 2011). Dengan transfer teknologi/hasil riset ini diharapkan dapat memecahkan masalah limbah buangan dan meningkatkan pendapatan pengusaha keripik di Sentra Industri Keripik. Lokasi IRT keripik dan lokasi pembuangan limbah buangan industri keripik di pinggir badan sungai tersaji pada Gambar 1 berikut.

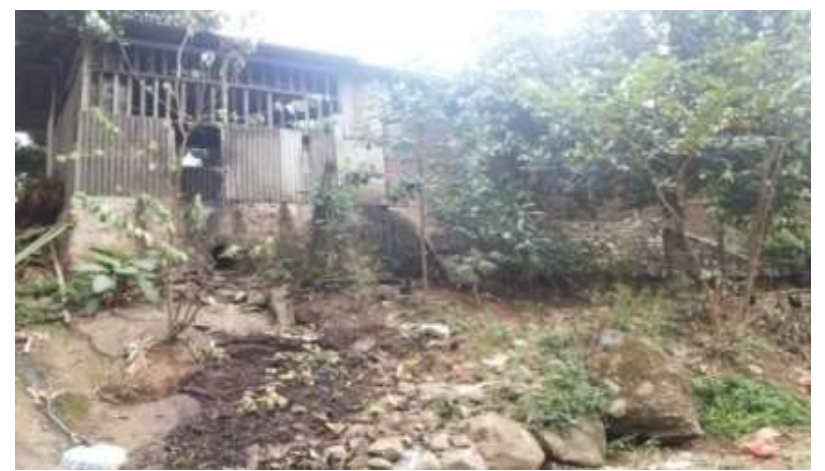

Gambar 1. lokasi pembuangan limbah buangan industri keripik di pinggir badan sungai (Sumber: dokumentasi pribadi)

Untuk mewujudkan program tersebut, maka Tim Program Hi-Link Unila dari PS THP dan PS TIP mencoba menjadi fasilisator untuk memecahkan masalah ini dengan cara diseminasi hasil riset. Pada Program pengabdian ini yang menjadi mitra adalah IRT keripik Zom-Zom dan Dua Dara.

Industri Rumah Tangga keripik Zom-Zom dan Dua dara telah berdiri sejak 2008 berlokasi di Gang PU, Jalan ZA Pagar Alam, Bandar Lampung. Lokasi kedua IRT ini saling berdekatan persis bersebelahan. Industri keripik tersebut memiliki berbagai produk diantaranya keripik pisang aneka rasa, keripik singkong, dan aneka keripik buah lainnya. Limbah hasil pengolahan tersebut masih dibuang begitu saja tanpa adanya pemnafaatan yang berarti, sehingga perlu dilakukan pembinaan terkait pengolahan limbah industri keripik yang dihasilkan, sehingga menghasilkan produk samping memiliki nilai tambah bagi IRT tersebut.

Pada sentra IRT keripik menghasilkan limbah buangan yaitu kulit, bonggol, tangkai buah. Limbah buangan ini dibuang di pinggir badan sungai tanpa pengolahan. Padahal limbah buangan keripik masih bisa diolah menjadi produk yang memiliki nilai jual misalnya menjadi kompos dan sumber anti mikroba alami. Kulit buah memiliki potensi sumber anti mikroba alami, misalnya kulit buah kulit buah pisang (Sartika dkk, 2017). Kulit buah pisang, naga, singkong, berpotensi dibuat menjadi anti mikroba alami karena mengandung, tanin, phenol, komponen karboksilat, dan asam organik (Sartika, 2017). Pada kosmetikyaitu sebagai sediaan untuk perawatan kulit, sampo, sediaan pewangi dan pasta gigi (Herdiana, 2007) Produk luaran anti mikroba alami bisa berupa hand sanitizer. Produk tersebut diatas di pasaran menggunakan anti bakteri/anti mikroba sintetis, yang berbahaya bila dipakai terus menerus. Sehingga berpotensi menggantikan produk yang ada di pasaran. Permasalahan mitra adalah minimnya pengetahuan pengolahan limbah dan diversifikasi produk, sehingga perlu (1) transfer teknologi pengolahan limbah buangan menjadi anti mikroba alami; (2) transfer teknologi diversifikasi produk anti mikroba alami; (3) transfer teknologi pengolahan produk hand sanitizer.

Dengan diseminasi hasil riset anti mikroba alami ini diharapkan selain dapat menyelesaikan permasalahan limbah buangan juga dapat meningkatkan pendapatan pengusaha keripik.

\section{METODE}

Metode kegiatan pengabdian ini adalah a) Ceramah dan diskusi diseminasi hasil riset dan b) pendampingan pengolahan limbah buangan menjadi produk anti mikroba alami berupa hand 
sanitizer. Kegiatan ini dilakuakan secara berkala dari 2019-2020. Penyampaian materi kegiatan pengabdian masyarakat akan dilaksanakan dengan metode ceramah, kemudian dilakukan diskusi (Tanya jawab) yang akan memberikan kesempatan pemahaman materi kepada peserta dalam melakukan proses atau menyampaikan permasalahan serta gagasan yang terkait dengan cara pemanfaatan fage pada industri pangan produksi yang baik.

Penerapan hasil riset yang akan disampaikan pada kegiatan pengabdian masyarakat dalam ceramah dan diskusi meliputi:

(1) Teknik pengolahan limbah buangan

(2) Teknik pengolahan diversifikasi limbah buangan

(3) Teknik pengolahan anti mikroba alami

(4) Teknik pengolahan Hand sanitizer

Pengumpulan dan analisis data pengabdian dilakukan dengan cara:

(1) Evaluasi awal ; dilakukan pada awal kegiatan pengabdian dengan cara memberikan quistioner diawal pengabdian

(2) Evaluasi akhir, dilakukan pada akhir kegiatan pengabdian masyarakat dengan memberikan tes akhir yang berupa kuestioner dengan pertanyaan yang sama dengan tes awal. Data untuk melihat seberapa jauh peningkatan pemahaman peserta sosialisasi dibandingkan dengan hasil evaluasi awal tes pertama.

Variable dengan menggunakan 5 pertanyaan dengan diberikan lembar quisioner sebelum dan setelah pelatihan, hal ini bertujuan untuk mengetahui presentase pemahaman terhadap materi yang telah diberikan. Berikut variable yang diberikan dalam lembar questioner :

1. Seberapa pemahaman anda terhadap pengolahan limbah kulit pisang?

2. Seberapa pemahaman anda terhadap pembuatan kompos dan pupuk cair dari limbah kulit pisang?

3. Seberapa besar pemahaman anda terhadap pembuatan pakan dari limbah kulit pisang?

4. Apakah anda mengetahui produk antimikroba? (ya/tidak) Seberapa besar pemahaman anda terhadap pembuatan antimikroba?

5. Seberapa besar pemahaman anda terhadap pembuatan handsanitizer?

\section{Pembuatan Hand Sanitizer}

Bahan baku yang dibutukan adalah: gel aloe vera (200 ml), ekstrak anti mikroba alami (15 ml), minyak pohon teh (30 tetes), minyak esensial misal lavender atau peppermint (5 tetes). Prosedur pembuatannya adalah: (1) pengadukan hazel, gel lidah buaya dan minyak pohon teh hingga homogen; (2) Penambahan cairan witch hazel agar tampilan lebih cair; (3) penambahan minyak essensial 3-5 tetes. (4) pencampuran dengan alat vorteks hingga homogen; (5) Pengemasan produk hand sanitizer dalam botol atau toples. ekstrak anti mikroba alami dapat dibuat dari kulit buah, menurut sartika (2017) kulit buah juga mengandung penol, tanin, asamasam organik misalnya asam askorbat yang berpotensi sebagai anti mikroba alami.

\section{Evaluasi pelaksanaan}

Pengabdian dilakukan dengan cara: a) evaluasi awal, dilakukan pada awal kegiatan pengabdian dengan cara memberikan quistioner diawal pengabdian, b) evaluasi akhir, dilakukan pada akhir kegiatan pengabdian masyarakat dengan memberikan tes akhir yang berupa kuestioner dengan pertanyaan yang sama dengan tes awal. Untuk mengetahui peningkatan pemahaman peserta sosialisasi data diolah dan hasilnya dibandingkan dengan hasil evaluasi awal tes pertama untuk melihat seberapa jauh peningkatan. Data yang telh diolah disajikan secara deskriptif.

\section{Keberlanjutan program}


Dilakukan dengan cara: a) Tim pengabdian akan tetap memberikan pendampingan pasca kegiatan pengabdian, b) akan dibuat ikon produk dengan logo "binaan unila" yang diharapkan bisa dibeli mahasiswa/dosen unila bahkan masyarakat, dan c) dijadikan oleh-oleh khas THP/lampung.

\section{HASIL DAN PEMBAHASAN}

\subsection{Hasil}

Kegiatan 1 adalah survey kebutuhan mitra yang urgen yang dilakukan oleh tim pengabdi unila (dewi sartika, susilawati, neti yuliana). Tim melakukan wawancara tentang: a) pengelolaan limbah di kawasan industri rumah tangga keripik, b) Pembuatan serbuk Anti Mikroba Alami, c) pembuatan soap soft, d) pembuatan hand sanitizer, e) pembuatan kemasan serbuk anti mikroba alami pangan dan f) pembuatan keripik. Hasil menunjukkan bahwa prosentase keinginan mitra berdasarkan survey yang dilakukan tersaji pada Gambar 2 dan Tabel 3 berikut:

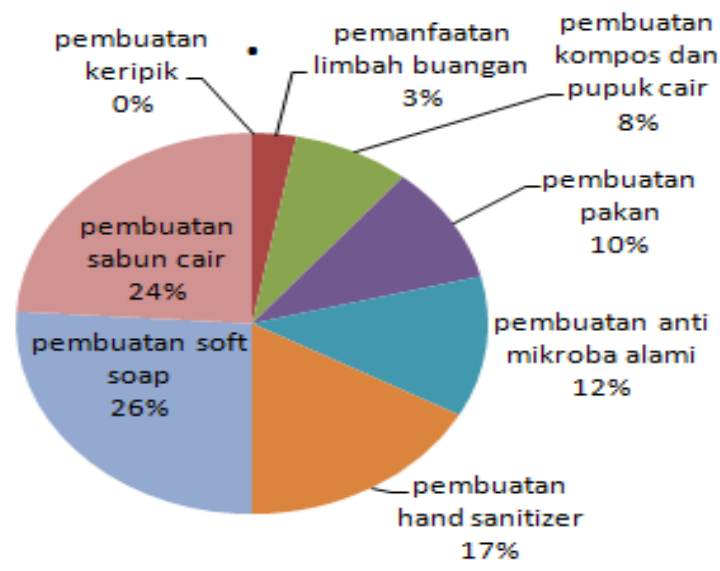

Gambar 2. Prosentase keinginan tahuan mitra untuk mengembangkan produk samping yang bernilai jual

\subsection{PEMBAHASAN}

Tabel 1. Peningkatan Prosentase pemahaman dan penguasaan ketrampilan terhadap materi sosialisasi yang disampaikan

\begin{tabular}{llccc}
\hline \multirow{2}{*}{ No } & Pengetahuan & \multicolumn{3}{c}{ Prosentase pemahaman } \\
& & $\begin{array}{c}\text { Awal } \\
(\%)\end{array}$ & $\begin{array}{c}\text { Akhir } \\
(\%)\end{array}$ & $\begin{array}{c}\text { Kenaikan } \\
(\%)\end{array}$ \\
\hline 1 & pemanfaatan limbah buangan & 10 & 50 & 40 \\
2 & pembuatan kompos dan pupuk cair & 20 & 70 & 50 \\
3 & pembuatan pakan & 20 & 60 & 40 \\
4 & pembuatan anti mikroba alami & 0 & 70 & 70 \\
5 & pembuatan hand sanitizer & 0 & 60 & 60 \\
\hline
\end{tabular}

Ternyata mitra menginginkan info pembuatan sabun padat herbal $26 \%$, diikuti sabun cair $24 \%$, hand sanitizer $17 \%$, anti mikroba alami $12 \%$, pembuatan pakan $10 \%$, pembuatan kompos dan pupuk cair 8\%. Uniknya mitra tidak meminta info atau sosialisasi tentang keripik, kemungkinan sudah banyak info tentang keripik.

Berdasarkan prosentase kebutuhan mitra: a) pembuatan keripik, b) pemanfaatan limbah buangan c) pembuatan kompos dan pupuk cair, d)pembuatan pakan e) pembuatan anti mikroba alami f) pembuatan hand sanitizer herbal, g) pembuatan soft soap herbal, h) pembuatan sabun cair herbal terlihat Prosentase terbesar adalah pada poin b, c, d, e, f, g, h, perlu mesin penghancur 
limbah buah pada proses pembuatan keripik sehingga tim memutuskan untuk melakukan pemberian mesin penghancur atau grinder (Gambar 3).

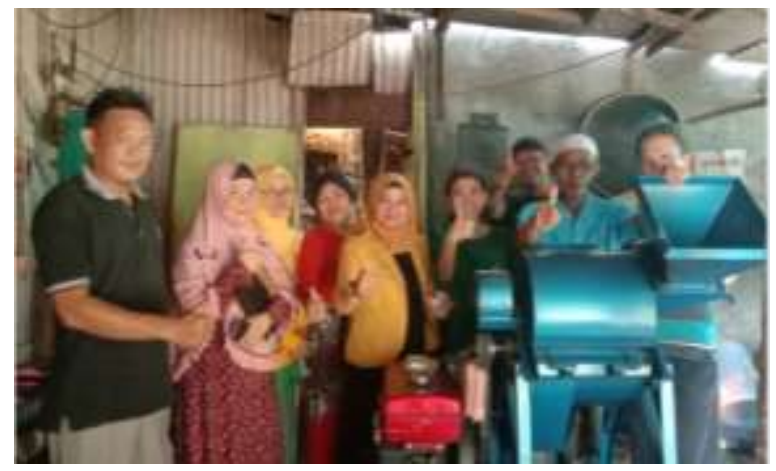

Gambar 3. Alat penghancur buangan organik industri keripik

Pembuatan hand sanitizer herbal, dilakukan di laboratorium dan disosialisasikan kepada masyarakat dengan cara demonstrasi dan praktek (Gambar 4). Diakhir kegiatan 3 dilakukan pembuatan video clip kegiatan Pembuatan hand sanitizer herbal.

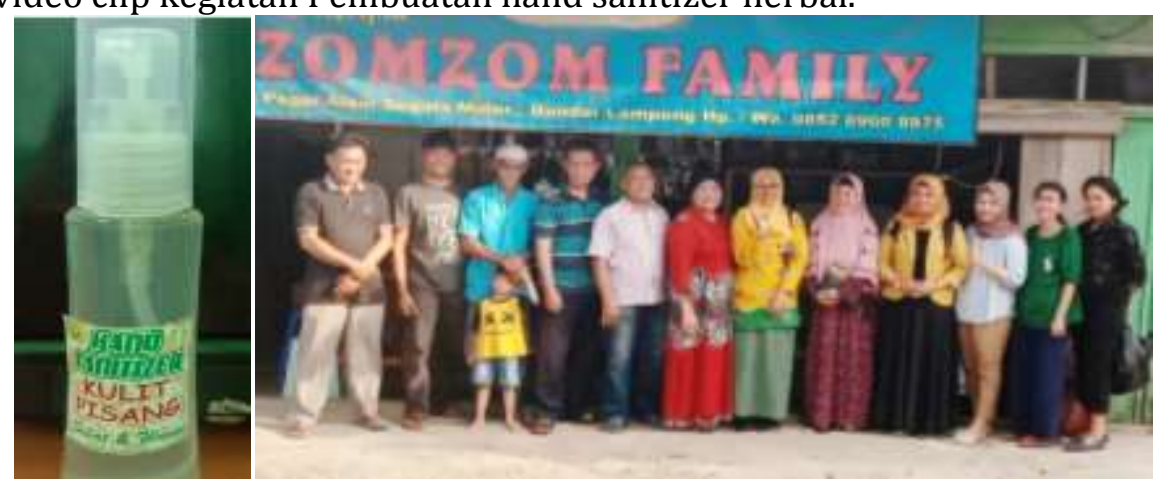

Gambar 4. Pembuatan hand sanitizer

Tim melakukan sosialisasi berupa ceramah dan demonstrasi materi-materi berikut: a) Pembuatan serbuk Anti Mikroba Alami, b) soft soap, c) pembuatan hand sanitizer, d) pembuatan kemasan serbuk anti mikroba alami.

\section{KESIMPULAN}

Kesimpulan dari kegiatan ini adalah

1. Kebutuhan saat ini mitra industri rumah tangga keripik untuk mengolah produk limbah/buangan menjadi produk yang mempunyai nilai adalah info pembuatan sabun padat herbal $26 \%$, diikuti sabun cair $24 \%$, hand sanitizer $17 \%$, anti mikroba alami $12 \%$, pembuatan pakan $10 \%$, pembuatan kompos dan pupuk cair $8 \%$.

2. Prosentase peningkatan pengetahuan dan pemahaman materi setelah kegiatan pengabdian adalah pemanfaatan limbah buangan (40\%), pembuatan anti mikroba alami (40\%), pembuatan hand sanitizer (70\%).

\section{UCAPAN TERIMA KASIH}

Ucapan terima kasih Tim Pengabdian THP di tujukan kepada UNILA yang telah mendanai program ini melalui HIBAH BLU Diseminasi Hasil Riset. 
Anwar, E. (2012). Eksipien dalam SediaanFarmasi. Dian Rakyat.

Arhany, D.F. (2011). Pemanfaatan Ekstrak Daun Beluntas (Pluchea indica Less.) sebagai Sediaan Gel Antiseptik Hand Sanitizer. UIN.Makasar.

Hartari, WR, Sartika D, and Suharyono AS. (2018). Using Ceara Rubber as Natural Anti-Microbe in Reducing Contamination of Staphylococcus aureus, Salmonella sp., Vibrio sp. and Escherichia coli in Mackerel Tuna Fish (Euthynnus affinis).Proceeding International Conference On Cassava, Bandar Lampung, November 23rd - 24th, 2017. ISBN 978-6020860-26-8. LPPM Unila published. pp:54-59

Iswandari, Sartika, D. And Astuti S. (2017). Aktivitas anti mikroba Alami Singkong (manihot utilisima). Laporan penelitian. 70 halaman.

Radji, M. (2010). Buku Ajar Mikrobiologi : Panduan Mahasiswa Farmasi dan Kedokteran. Penerbit Buku Kedokteran EGC. Jakarta.

Rasidy, G. 2006. Manfaat Penggunaan Antiseptik Kombinasi AlkoholChlorhexidine GluconateEmolien Dibandingkan Dengan Chlorhexidine Gluconate Terhadap Jumlah Bakteri Pada Tangan Perawat Di Perinatologi, ICU Anak,NICU RSCM.

Retno, S., Isadiartuti, D. (2005) Uji efektifitas sediaan gel antiseptic tangan yang mengandungetanol dan triklosan. Majalah Farmasi Airlangga.

Sartika D, Herdiana N, Kusuma SN. (2017). Kajian Daya Hambat Ekstrak Kulit Dan Jantung Pisang Muli (Musa Acuminata) Sebagai Antimikroba Alami Dalam Menurunkan Cemaran Echerichia Coli Pada Daging Ayam (Gallus Domesticus).Laporan Penelitian. Bandar lampung. 65 halaman.

Sartika D, Suharyono A.S, and Putri FD. (2018). Study Control Of Salmonella Sp. contamination On White Shrimp (Litopenaeus Vannamei) Using Natural Antimicrobial From Extract of Cherry Tomatoes Fruits (Lycopersicum Cerasiformae Mill.) Proceeding Of Isae International Seminar:"Strengthening Food and Feed Security and Energy Sustainability to Enhance Competitiveness" Bandar Lampung, August 10-12, 2017. ISBN : 978-602-72006-2-3. Dept of Agricultural Engineering, Unila Published. p: 531-538.

Sartika D, Sutikno, Syarifah R.M. (2018). The Profile Of Red Dragon Fruit Peel Extract As A Natural Antimicrobials In Reducing E. Coli. Proceeding of Isae International Seminar:"Strengthening Food and Feed Security and Energy Sustainability to Enhance Competitiveness" Bandar Lampung, August 10-12, 2017. ISBN : 978-602-72006-2-3. Dept of Agricultural Engineering, Unila Published. p: 565-568.

Sartika, D dan Sutikno. (2016). Aktivitas Antimikroba Alami dari kulit nenas dan kulit jeruk. Laporan Penelitian. Bandar Lampung. 75 hal.

Sartika, D, Budiarti S, and Mirnawati. (2012). Bacteriophage (Phage) FR38 Treatment on Sprague Dawley Rat Inferred from Blood Parameters and Organ Systems. J.Hayati of Biosci: 19(3)

Sartika, D, Budiarti S, and Mirnawati. (2012). Safety The Effect Of Indigenous Salmonella P38 Phage (Phage Fr38) On Sprague Dawley Strain Rat. J HAYATI J. of Biosci. Vol. 19 No. 3, p 131136.

Sartika, D. (2012). Efektifitas Lisis dan Keamanan Phage Fr38 [Disertasi]. Bogor: Bogor Agricultural Univ.

Sartika, D. (2018). Bacteriophage (Fage) Sebagai Biokontrol Alami Pada pangan dan Lingkungan Pada Pangan. Penerbit Graha Ilmu. 109 halaman.

Sartika, D. (2018). Cemaran Bakteri Patogen Pada Pangan (Uji Kualitatif dan Kuantitatif). Penerbit Graha Ilmu. 109 halaman.

Syarifudin, H dan Hamzah. (2019). Prospek pemanfaatan limbah batang pisang dalam mendukung ekonomi kreatif masyarakat ramah lingkungan. J Dinamisia. Vol. 3, 27-34.

Undadraja, B and Sartika, D. (2018). Identifying Chemical Compound in Ceara Rubber Skin Which Is Potential To Be Natural Anti-Microbe By Using Gas Chromatography-Mass Spectrometry (GCMS). Proceeding International Conference On Cassava, Bandar Lampung, November 23rd - 24th, 2017. ISBN 978-602-0860-26-8. LPPM Unila published. pp: 24-27. 